\title{
Farmers' Perception of Performance Performed by Extension Field Workers/ Facilitators during Integrated Pest Management Farmer Field School Training Programme in Sindh Province of Pakistan
}

\author{
A. A. Siddiqui ${ }^{1}$ and M. Siddiqui ${ }^{2}$ \\ ${ }^{1}$ Agriculture Extension Wing, Hyderabad, Sindh, Pakistan \\ ${ }^{2}$ Department of Commerce, University of Sindh, Jamshoro, Pakistan. \\ akhtarsidiki@hotmail.com
}

\begin{abstract}
In connection to environment friendly farming, potential stakeholders took efforts and launched FAO-EU-ADB funded National Integrated Pest Management (Nat-IPM) Programme for Cotton in Pakistan during the years 2001 to 2004 and introduced new extension training methodology called Farmer Field School (FFS). The basic principle of FFS training was to enable farmers to be self sufficient, using IPM practices that are agro-ecosystem friendly. This study examined the performance performed by agriculture extension field workers/facilitators $(\mathrm{EFW} / \mathrm{F})$ in the implementation of IPM-FFS trainings with special reference to cotton crop in selected districts of Sindh province of Pakistan. A survey study was carried out in four districts of Sindh province (Hyderabad, Tando Allahyar, Matiari and Mirpurkhas). The total sample size comprised of 144 farmers who were involved in the series of IPM-FFS training sessions. Farmers' perceived that EFW/F played an effective role and performed positively in IPM-FFS activities during training programme. Further, results of present study a confirmation of the adoption and a validation of IPM-FFS as a successful extension approach in Sindh province of Pakistan.
\end{abstract}

Keywords: Good Agricultural Practice, IPM-FFS, Extension Field Worker, AgroEcosystem.

\section{Introduction}

Pakistan is the territory of cotton (Gossypium hirsutum L.) and big source of livelihood to around 1.5 million farmers in the rural areas. Cotton is a main source of export capital, accounts for 6.9 percent of value added in agriculture and 1.4 percent of GDP. Pakistan is the world's 4th biggest cotton producing 
country after China, India, and USA. The world cotton production is projected at 24.8 million tons, during 2010-11 as against 22.01 million tons recorded in 2009-10, estimating an increase of 12.6 percent. Production is expected to continue to increase 11 percent to a record of 27.6 million tons in 2011-12 (GoP, 2011).

Despite of being one of the largest cotton growing countries, the cotton production in Pakistan is low as compared to other countries. Low cotton production is for the reason of weather conditions, pests attack and little awareness of applying scientific and pest curbing techniques by farmers. The timely and optimum use of the pesticides for cotton is essential to prevent the crop from the attack of pests and diseases but the excessive use of the pesticides disrupts the growth of cotton, killing cotton friendly pests and providing opportunity to harmful pests to attack on crop. Also, this throws burden of costs on the growers. Moreover, farmers uses variety of pesticides in cotton to eliminate insects and weeds from their fields, but these limiting agents have the potential to harm our health and the environment (FAO, 2004). The research must provide those methods that are affordable to the farmers and the environment friendly. The Integrated Pest Management-Farmer Field School (IPM-FFS) approach is based on training needs. The farmers participate in the FFS and become a part of wide scale IPM programmes, ranging from local to national research, and analyze the production troubles and develop solutions for them at the country level (FAO, 2000). The collective research with farmers involves information about local conditions, local-ecosystem, and weather. The IPM-FFS takes into consideration local needs as well (Linh, 2001).

Various studies regarding Integrated Pest Management (IPM) programmes were agreed in end that Farmer Field School (FFS) strengthens farmers' ecological knowledge (Thiele et al., 2001; Rola et al., 2002; Feder et al., 2004; Reddy and Suryamani, 2005; Tripp et al., 2005). The information about understanding the crop ecosystem leads reduction in the pesticides use and at the same time increases production and profit, for instance, in the cotton production systems (Godtland et al., 2004; Khan et al., 2005). The FFS is a training model developed primarily by Food and Agriculture Organization (FAO) in which farmers gain the decision making power regarding use of agro-chemicals at their field. This unique extension approach is actionlearning oriented where farmers are allowed to observe, analyze and make alternative decision about their crops (Kingsley, 1999).

During the four years 2001 to 2004, Sindh province has embraced IPM-FFS as the dominant interface between agriculture extension and farmers. It was assumed that through this new training approach, EFW/F would change the farmers' traditional role from passive learner to active learner. The purpose of this study was to record farmers' perception about the performance performed 
by $\mathrm{EFW} / \mathrm{F}$ and to identify the barriers/constraints faced by farmers during IPM-FFS training programme in selected districts of Sindh province.

\section{Methodology}

The literature review indicated that various research designs were used to measure the perception of farmers including self-report measures, observations, and personal interviews. In view of the proposed study thus featured a descriptive survey research. Descriptive survey research has evolved over the years to become a popular methodology among educational researchers (McMillan, 2008).

Four Districts of Sindh province were selected as study area viz., Hyderabad, Tando Allahyar, Matiari and Mirpurkhas district, where IPM-FFSs were established during 2001 to 2004 for cotton through Nat-IPM programme. List of the farmers who were trained in IPM-FFS training programme obtained from National IPM programme coordinator, Director General, Agricultural Extension Wing, Hyderabad, Sindh. After obtaining the list, a sample size of 144 was determined using "Table for Determining Random Sample Size from a Given Population" (Fitz-Gibbon and Morris, 1987; Wunsch, 1986) at confidence level $95 \%$ with margin of error $\pm 5 \%$.

Questionnaire was developed in consultation with the IPM-FFS experts and help of available literature. The concepts or ideas were usually measured through different statements on a continuum ranging from negative to positive. A five (5) point likert scale (1=Never, 2=Rarely, 3=Sometimes, 4=Often and $5=$ Always) was employed for computing farmers' attendance and application of activities conducted by EFW/F while IPM-FFS training and twenty three (23) performance related statements were developed for measuring the farmers' perception of overall performance of EFW/F by using likert scale (1=Strongly unfavourable, 2=Somewhat unfavourable, 3=Undecided, 4=Somewhat favourable and $5=$ Strongly favourable). The barriers faced by the farmers 'during IPM-FFS activities were also ranked. Survey was conducted for this study during the period March to September 2009. Despite several efforts, a total response rate $(93.75 \%)$ was obtained. IBM-SPSS version 19 was used for data analysis. Frequency, mean, percentage, and standard deviation were calculated.

\section{Results and Discussion}

\section{Demographic Information}

The demographic characteristics of the sampled farmers are presented in Table-1 that shows most of the farmers (28.1\%) were young and falling into 
the age grouped of 21-30 years. The educational level of farmers was not good; majority of them $(27.4 \%)$ educated only up to primary level. Most of them $(27.4 \%)$ were owners of land in between the range of 11 to 20 acres. Large number of (36.3\%) farmers had farming experience in the range of 11 to 20 years followed by less than 10 years of experience $(29.6 \%)$. Majority of the farmers $(25.9 \%$ ) had their farm yearly income more than 100,000/- (pak rupees) followed by farm income in the range of 41,000 to $60,000(23.0 \%)$ farmers.

Table 1: Demographic information of respondents

\begin{tabular}{|c|c|c|c|}
\hline \multirow{2}{*}{$\begin{array}{l}\text { Characteristics } \\
\text { (Scoring Method) }\end{array}$} & \multirow{2}{*}{ Category } & \multicolumn{2}{|c|}{ Farmers $(n=144)$} \\
\hline & & Frequency & Percentage \\
\hline \multirow{5}{*}{ Age (Years) } & Less than 20 & 25 & 18.5 \\
\hline & 21 to 30 & 38 & 28.1 \\
\hline & 31 to 40 & 30 & 22.2 \\
\hline & 41 to 50 & 23 & 17.0 \\
\hline & $51 \&$ above & 19 & 14.1 \\
\hline \multirow{7}{*}{$\begin{array}{l}\text { Educational level } \\
\text { (Year of schooling) }\end{array}$} & Illiterate $(0)$ & 26 & 19.3 \\
\hline & Primary $(1-5)$ & 37 & 27.4 \\
\hline & Middle $(6-8)$ & 24 & 17.8 \\
\hline & Matriculate (9-10) & 11 & 8.1 \\
\hline & Intermediate (11-12) & 13 & 9.6 \\
\hline & Graduate (13-16) & 15 & 11.1 \\
\hline & Post Graduate (17 \& above) & 9 & 6.7 \\
\hline \multirow{5}{*}{ Farm Size (Acres) } & Less than 10 & 27 & 20.0 \\
\hline & 11 to 20 & 37 & 27.4 \\
\hline & 21 to 30 & 30 & 22.2 \\
\hline & 31 to 40 & 21 & 15.6 \\
\hline & $41 \&$ above & 20 & 14.8 \\
\hline \multirow{5}{*}{$\begin{array}{l}\text { Farming Experience } \\
\text { (Years) }\end{array}$} & Less than 10 & 40 & 29.6 \\
\hline & 11 to 20 & 49 & 36.3 \\
\hline & 21 to 30 & 23 & 17.0 \\
\hline & 31 to 40 & 15 & 11.1 \\
\hline & $41 \&$ above & 8 & 5.9 \\
\hline \multirow{6}{*}{$\begin{array}{l}\text { Farm Yearly Income } \\
\text { (Pak rupees) }\end{array}$} & Up to 20,000 & 7 & 5.2 \\
\hline & 21,000 to 40,000 & 27 & 20.0 \\
\hline & 41,000 to 60,000 & 31 & 23.0 \\
\hline & 61,000 to 80,000 & 15 & 11.1 \\
\hline & 81,000 to 100,000 & 20 & 14.8 \\
\hline & 100,000 and above & 35 & 25.9 \\
\hline
\end{tabular}

\section{Motivation for participation in IPM-FFS training:}

The farmers were enquired to disclose the means of their engagement/ motivation for participation in IPM-FFS training programme and the responses of farmers are presented in Table 2. The results show that majority of the farmers $(51.1 \%)$ perceived that they participated in IPM-FFS on their self interest, and 11.9 percent of the farmers reasoned their training participation on request of the farm manager; while 8.9 percent showed cause of their 
participation as order of their landlord. Similarly, 28.1 percent of the farmers perceived that they were motivated by the EFW/F to participate in IPM-FFS training programme. Results indicate that the farmers have interest to engage in IPM-FFS training for improving their farming capabilities. These findings were supported by Khan et al. (2005) who carried out study an assessment on IPM-FFS training programme on farmers' capabilities, practices and profits in the Khairpur district of Sindh province. The study demonstrated that the whole season-long IPM-FFS training developed farming and decision making capabilities of farmers.

Table 2: Farmers' engagement in IPM-FFS training

\begin{tabular}{|l|c|c|}
\hline \multirow{2}{*}{ Category } & \multicolumn{2}{c|}{ Farmers (n= 144) } \\
\cline { 2 - 3 } & Frequency & Percentage \\
\hline Self Interest & 69 & 51.1 \\
\hline Requested by Farm Manager & 16 & 11.9 \\
\hline Land Lord Ordered & 12 & 8.9 \\
\hline Motivated by EFW/F & 38 & 28.1 \\
\hline
\end{tabular}

\section{Regularity of farmers in IPM-FFS training:}

While gathering the information regarding the regularity of the farmers in IPM-FFS training, results showed that vast majority of the farmers $(83.7 \%)$ indicated that they regularly attended IPM-FFS, which is promising professionalism attitude of farmers towards training programme. Braun and Duveskog (2010) stated that usually IPM-FFS trained farmers become good facilitators because they are practical and well-known about their community.

\section{Farmers' perception of IPM-FFS activities conducted by EFW/F:}

The data is reported in Table 3, mean ranking showed that most of the activities conducted as 'always' i.e. 73.3 percent of the respondents practiced activity was 'review of previous session' ( $4.55 \pm 0.88)$, 97.8 percent, 'Cotton ecosystem analysis' (4.98 \pm 0.14$), 45.2$ percent, 'field trials/experiments' $(4.09 \pm 1.06)$, while 50.4 percent 'insect zoo' $(4.28 \pm 0.91)$. Regarding energizer activity, scattered responses were received $(3.83 \pm 1.04)$, but 'sheet preparation' as majority of the farmers reported that they 'always' conducted (4.94 \pm 0.26$)$, 'group discussion' 73.3 percent $(4.61 \pm 0.78)$. The 'special topic' was the average activity reported conducted in IPM-FFS, scattered responses from 'never' to 'always' but mean regularity $(3.41 \pm 1.12)$ considered as 'often'; the respondents perceived responses for the activity of 'group dynamic exercise' (3.91 \pm 1.06$)$ but 'session review', 73.3 percent showed that most of activities were 'always' conducted in IPM-FFS training sessions $(4.59 \pm 0.81)$. The results of present study are also in line with those reported by Mallah and Korejo (2007) who noted that IPM-FFS programme made a visible impact on farmers understanding; and one of the 
main reason for the success of this approach is that the decisions are not preplanned and based on the analysis of agro-ecosystem practiced by the farmers himself with the help of facilitators.

Table 3: Farmers' perception of IPM-FFS activities conducted by EFW/F

\begin{tabular}{|l|l|c|c|c|c|c|c|c|}
\hline \multicolumn{2}{|c|}{ IPM-FFS Activities } & Never & Rarely & Sometimes & Often & Always & \multirow{2}{*}{ M } & \multirow{2}{*}{ SD } \\
\cline { 3 - 7 } & P & P & P & P & P & & \\
\hline 1 & Review Previous Session & 0.7 & 5.9 & 4.4 & 15.6 & 73.3 & 4.55 & 0.88 \\
\hline 2 & Ecosystem Analysis & 0.0 & 0.0 & 0.0 & 2.2 & 97.8 & 4.98 & 0.14 \\
\hline 3 & Field Trials/Experiments & 4.4 & 3.0 & 17.0 & 30.4 & 45.2 & 4.09 & 1.06 \\
\hline 4 & Insect Zoo & 1.5 & 4.4 & 8.9 & 34.8 & 50.4 & 4.28 & 0.91 \\
\hline 5 & Energizer & 2.2 & 10.4 & 19.3 & 38.5 & 29.6 & 3.83 & 1.04 \\
\hline 6 & Sheet Preparation & 0.0 & 0.0 & 0.7 & 4.4 & 94.8 & 4.94 & 0.26 \\
\hline 7 & Group Discussion & 1.5 & 2.2 & 3.0 & 20.0 & 73.3 & 4.61 & 0.78 \\
\hline 8 & Special Topic & 5.2 & 15.6 & 31.9 & 28.1 & 19.3 & 3.41 & 1.12 \\
\hline 9 & Group Dynamic Exercise & 2.2 & 8.1 & 23.7 & 28.1 & 37.8 & 3.91 & 1.06 \\
\hline 10 & Session Review & 1.5 & 2.2 & 5.2 & 17.8 & 73.3 & 4.59 & 0.81 \\
\hline
\end{tabular}

$\mathbf{P}=$ Percentage, $\mathbf{M}=$ Mean, $\mathbf{S D}=$ Standard Deviation

\section{Farmers' perception of overall performance of EFW/F:}

The twenty three (23) different statements were developed for measuring the farmers' perception of overall performance performed by EFW/F during IPM-FFS training programme and it was found that on the most of statements farmers' perceived 'Somewhat favourable' and 'Strongly favourable', showing highly positive attitude in relation to performance performed by EFW/F during IPM-FFS training programme. The data gathered to this regard (Table 4) indicate that the 74.1 percent of the respondents 'Somewhat favourable' that 'EFW/F were active and energetic during IPM-FFS training' and 19.3 percent 'Strongly favourable' over this statement. The 'EFW/F involved himself and was flexible in participation in IPM-FFS activities' was 'Somewhat favourable' by 58.5 percent farmers and 29.6 percent 'Strongly favourable'; while 66.7 percent respondents 'Somewhat favourable' that 'EFW/F conducted IPM-FFS activities step by step in an organized manner' while 'Strongly favourable' by 18.5 percent respondents. On the statement that 'EFW/F used appropriate methods and kept focus on the IPM-FFS continuing activities' 71.1 percent respondents were 'Somewhat favourable' and 14.8 percent were 'Strongly favourable'; while sixty percent 'Somewhat favourable' that 'EFW/F used practical examples for understanding of farmers and to stimulated discussion' and 17.8 percent farmers 'Strongly favourable' on this statement. Similarly, 51.1 percent farmers were 'Somewhat favourable' that 'EFW/F used the group dynamics exercises and ice breaker in an appropriate time' and 26.7 percent were 'Strongly favourable'. However, 64.4 percent were 'Somewhat favourable' that 'EFW/F created space for every participant to involve in the discussion through brain storming' and 18.25 percent 'Strongly favourable' on this statement. 


\begin{tabular}{|c|c|c|c|c|c|c|c|c|}
\hline \multirow{2}{*}{\multicolumn{2}{|c|}{ Statements About EFW/F Performance }} & $\begin{array}{l}\text { Strongly } \\
\text { unfavourable }\end{array}$ & $\begin{array}{l}\text { Somewhat } \\
\text { unfavourable }\end{array}$ & Undecided & $\begin{array}{l}\text { Somewhat } \\
\text { favourable }\end{array}$ & $\begin{array}{l}\text { Strongly } \\
\text { favourable }\end{array}$ & \multirow[t]{2}{*}{ M } & \multirow[t]{2}{*}{ SD } \\
\hline & & Percentage & Percentage & Percentage & Percentage & Percentage & & \\
\hline 1 & $\begin{array}{l}\text { EFW/F seemed active and energetic } \\
\text { during conducted the IPM-FFS } \\
\text { training. }\end{array}$ & 1.5 & 0.7 & 4.4 & 74.1 & 19.3 & 4.09 & 0.62 \\
\hline 2 & $\begin{array}{l}\text { EFW/F involved himself and was } \\
\text { flexible in participation in all IPM- } \\
\text { FFS activities. }\end{array}$ & 0.7 & 2.2 & 8.9 & 58.5 & 29.6 & 4.14 & 0.72 \\
\hline 3 & $\begin{array}{l}\text { EFW/F conducted IPM-FFS activities } \\
\text { step by step and in an organized } \\
\text { manner that farmers felt easy. }\end{array}$ & 2.2 & 2.2 & 10.4 & 66.7 & 18.5 & 3.97 & 0.76 \\
\hline 4 & $\begin{array}{l}\text { EFW/F used appropriate methods and } \\
\text { kept focus on the IPM-FFS continuing } \\
\text { activity. }\end{array}$ & 1.5 & 4.4 & 8.1 & 71.1 & 14.8 & 3.93 & 0.73 \\
\hline 5 & $\begin{array}{l}\text { EFW/F used practical examples for } \\
\text { understanding of farmers and to } \\
\text { stimulate discussions. }\end{array}$ & 3.7 & 12.6 & 5.9 & 60.0 & 17.8 & 3.76 & 1.01 \\
\hline 6 & $\begin{array}{l}\text { EFW/F used the energizers/group } \\
\text { dynamics exercises and ice breakers } \\
\text { in an appropriate time. }\end{array}$ & 3.7 & 5.2 & 13.3 & 51.1 & 26.7 & 3.92 & 0.97 \\
\hline 7 & $\begin{array}{l}\text { EFW/F created space for every } \\
\text { participant to involve in discussions } \\
\text { through brain storming. }\end{array}$ & 4.4 & 5.9 & 6.7 & 64.4 & 18.5 & 3.87 & 0.93 \\
\hline 8 & $\begin{array}{l}\text { EFW/F tried to manage time properly } \\
\text { to complete IPM-FFS activities in set } \\
\text { schedule. }\end{array}$ & 3.0 & 5.2 & 11.1 & 63.7 & 17.0 & 3.87 & 0.86 \\
\hline 9 & $\begin{array}{l}\text { EFW/F also monitored and evaluated } \\
\text { the IPM-FFS to achieve the objectives. }\end{array}$ & 6.7 & 10.4 & 13.3 & 48.1 & 21.5 & 3.67 & 1.12 \\
\hline 10 & $\begin{array}{l}\mathrm{EFW} / \mathrm{F} \text { dealt very softly and politely } \\
\text { throughout the IPM-FFS that farmers } \\
\text { respected him a lot. }\end{array}$ & 0.7 & 2.2 & 3.7 & 75.6 & 17.8 & 4.07 & 0.60 \\
\hline 11 & $\begin{array}{l}\text { EFW/F communicated with the } \\
\text { farmers in a local language that } \\
\text { farmers picked up easily. }\end{array}$ & 0.7 & 4.4 & 8.1 & 48.9 & 37.8 & 4.19 & 0.82 \\
\hline 12 & $\begin{array}{l}\text { EFW/F believed in two ways } \\
\text { communication process so that } \\
\text { farmers didn't hesitate. }\end{array}$ & 1.5 & 3.0 & 5.2 & 67.4 & 23.0 & 4.07 & 0.72 \\
\hline 13 & $\begin{array}{l}\text { EFW/F involved farmers in decisions } \\
\text { making process through participatory } \\
\text { approach. }\end{array}$ & 4.4 & 6.7 & 5.9 & 63.0 & 20.0 & 3.87 & 0.95 \\
\hline 14 & $\begin{array}{l}\text { EFW/F listened questions completely } \\
\text { and carefully before replying to the } \\
\text { participant. }\end{array}$ & 0.7 & 4.4 & 5.9 & 60.0 & 28.9 & 4.12 & 0.76 \\
\hline 15 & $\begin{array}{l}\text { EFW/F always responded to the } \\
\text { participants' question timely and in a } \\
\text { consistent manner. }\end{array}$ & 5.9 & 6.7 & 9.6 & 57.0 & 20.7 & 3.80 & 1.03 \\
\hline 16 & $\begin{array}{l}\text { EFW/F identified and resolved the } \\
\text { issues of farmers related with the } \\
\text { IPM-FFS. }\end{array}$ & 3.0 & 5.2 & 12.6 & 56.3 & 23.0 & 3.91 & 0.91 \\
\hline 17 & $\begin{array}{l}\text { EFW/F really handled and resolved } \\
\text { the conflicts among farmers very } \\
\text { professionally. }\end{array}$ & 1.5 & 7.4 & 11.1 & 62.2 & 17.8 & 3.87 & 0.84 \\
\hline 18 & $\begin{array}{l}\text { EFW/F accepted criticism for self } \\
\text { appraisal and tried to improve his } \\
\text { facilitation skills. }\end{array}$ & 3.0 & 5.2 & 3.7 & 65.2 & 23.0 & 4.00 & 0.86 \\
\hline 19 & $\begin{array}{l}\text { EFW/F attitude was neutral and } \\
\text { natural with participants during IPM- } \\
\text { FFS activities. }\end{array}$ & 2.2 & 3.7 & 5.2 & 45.9 & 43.0 & 4.24 & 0.88 \\
\hline 20 & $\begin{array}{l}\mathrm{EFW} / \mathrm{F} \text { appreciated and encouraged } \\
\text { the farmers to build their confidence. }\end{array}$ & 3.0 & 5.9 & 6.7 & 66.7 & 17.8 & 3.90 & 0.86 \\
\hline 21 & $\begin{array}{l}\mathrm{EFW} / \mathrm{F} \text { had an ability to interact } \\
\text { with all farmers and kept them active } \\
\text { during the entire session. }\end{array}$ & 3.7 & 5.9 & 9.6 & 53.3 & 27.4 & 3.95 & 0.97 \\
\hline 22 & $\begin{array}{l}\text { EFW/F showed his full cooperation } \\
\text { with the farmers during the entire } \\
\text { IPM-FFS. }\end{array}$ & 1.5 & 6.7 & 4.4 & 54.8 & 32.6 & 4.10 & 0.87 \\
\hline 23 & $\begin{array}{l}\text { No doubt that extension field worker } \\
\text { was a well trained and technically } \\
\text { sound facilitator. }\end{array}$ & 2.2 & 3.7 & 5.9 & 65.9 & 22.2 & 4.02 & 0.79 \\
\hline
\end{tabular}

\section{$\mathbf{P}=$ Percentage, $\mathbf{M}=$ Mean, $\mathbf{S D}=$ Standard Deviation}


It was noted that 63.7 percent farmers 'Somewhat favourable' on 'completion of IPM-FFS activities at scheduled time by EFW/F' and 17 percent 'Strongly favourable' this management statement of EFW/F; 48.1 percent respondents were 'Somewhat favourable' on 'monitoring and evaluation by EFW/F in IPMFFS to achieve objectives' and 21.5 percent farmers were 'Strongly favourable' over this statement. Seventy five percent farmers were 'Somewhat favourable' over the 'soft and polite attitude of EFW/F during IPM-FFS sessions' and 17.8 percent 'Strongly favourable' this attitude. Against the statement that 'EFW/F communicated with farmers in local language' 48.9 percent participants were 'Somewhat favourable' and 37.8 percent respondents were 'Strongly favourable' with this statement; while 67.4 percent respondents 'Somewhat favourable' that EFW/F believed in two ways communication process so that farmers didn't hesitate' and this style was 'Strongly favourable' by 23 percent farmers. The data further shows that 63 percent farmers perceived as 'Somewhat favourable' over the statement that 'EFW/F involved farmers in decision making process through participatory approach' and 20 percent were 'Strongly favourable'; while on the statement that 'EFW/F listened questions completely and carefully before replying to the participant' 60 percent farmers 'Somewhat favourable' and 28.9 percent 'Strongly favourable' over this. The 20.7 percent farmers were 'Strongly favourable' that 'EFW/F always responded to the participants' question timely and in a consistent manner.' and this statement was 'Somewhat favourable' by 57 percent farmers.

Similarly, 56.3 percent farmers 'Somewhat favourable' that 'EFW/F identified and resolved the issues of farmers related with the IPM-FFS' while this statement was 'Strongly favourable' by 23 percent farmers; while 62.2 percent farmers were 'Somewhat favourable' over the statement that ' $\mathrm{EFW} / \mathrm{F}$ really handled and resolved the conflicts among farmers very professionally' and 17.8 percent 'Strongly favourable'. However, 65.2 percent participants 'Somewhat favourable' that 'EFW/F accepted criticism for self appraisal and tried to improve his facilitation skills' and this statement was 'Strongly favourable' by 23 percent farmers; while 45.9 percent respondents 'Somewhat favourable' that 'EFW/F attitude was neutral and natural with FFS participants' and this was 'Strongly favourable' by 43 percent farmers. The statement 'EFW/F appreciated and encouraged the farmers to build their confidence' was 'Somewhat favourable' by 66.7 percent participants and 'Strongly favourable' by 17.8 percent farmers; while 53.3 percent farmers 'Somewhat favourable' that $\mathrm{EFW} / \mathrm{F}$ had an ability to interact with all farmers and kept active during the entire session' and 'Strongly favourable' by 27.4 percent. Similarly, 54.8 percent farmers 'Somewhat favourable' that EFW/F showed his full cooperation with the farmers during the entire session of IPM-FFS' and 32.6 percent 'Strongly favourable' this statement; while 65.9 percent farmers stated 'Somewhat favourable' that no doubt that EFW/F was a well trained and technically sound person' and 22.2 percent 'Strongly favourable' this statement. The mean and 
standard deviation of the responses according to the likert scale indicates that the farmers were 'Somewhat favourable' with the performance of EFW/F at IPM-FFS platform. The same results were reported by Kenmore (2002) who stated that IPM-FFS is a training approach that trains farmers to compare new techniques in systematic field assessment and it prepares extension agents for their new roles as facilitator and representatives of public problems and difficulties such as environmental conservation, health, social involvement and organization. In another report Bartlett (2005) stated that the FFS training model for extension in Asia have involved over two million farmers in more than a dozen countries, supported by agriculture extension and international agencies. Across Asia, FFS helped hundreds of thousands farmers to learn IPM practices, about agro-ecological concepts, indiscriminate use of pesticides and increase crop yields.

\section{Ranking of barriers faced by farmer during IPM-FFS training:}

The barriers/constraints faced by the farmers during IPM-FFS activities were ranked and according to the farmers' perception (Table 5) IPM-FFS activities were time consuming, lack of incentives, lack of mutual understanding among farmers, strict and hectic schedule, sometimes facilitator behavior and discouraging attitude of the pesticide/fertilizer dealers were main barriers/ constraints. Despite the facing problems during IPM-FFS, famers' interest in training shows realization about the indiscriminate use of pesticides as well as benefits of environmentally sound IPM practices. Somewhat similar findings were found by Chukwuone, et al. (2006) who described that major constraints that affect technology transfer process are extension system lapses, lack of cooperation by farmers, uncertainties experienced in agriculture, and conflicts among farmers.

Table 5: Rank wise barriers/constraints faced by farmers

\begin{tabular}{|l|c|}
\hline \multicolumn{1}{|c|}{ Barriers/Constraints } & Rank Order \\
\hline IPM-FFS activities were difficult and time consuming. & 1 st \\
\hline $\begin{array}{l}\text { There was no extra benefit of adopting agro-ecological sound IPM } \\
\text { practices. }\end{array}$ & 2 nd \\
\hline $\begin{array}{l}\text { There was lack of participatory approach among farmers during IPM- } \\
\text { FFS training. }\end{array}$ & 3 rd \\
\hline $\begin{array}{l}\text { Participants lost interest in IPM-FFS training due to strict and hectic } \\
\text { schedule. }\end{array}$ & 4th \\
\hline $\begin{array}{l}\text { Facilitator usually not replied the questions so it was embracing for } \\
\text { farmers, participating in IPM-FFS training. }\end{array}$ & 5 th \\
\hline $\begin{array}{l}\text { Influence of pesticide dealers discouraged FFS participants to follow } \\
\text { IPM practices. }\end{array}$ & 6 th \\
\hline
\end{tabular}

\section{Conclusion}

IPM-FFS have been deployed around the country. However assessment with regard to performance performed by EFW/F was needed. The results 
of this study revealed that the EFW/F performed positively and effectively in activities during Integrated Pest Management Farmer Field School (IPMFFS) training programme in Sindh province as farmers showed positive attitude in relation to overall performance performed by EFW/F. Despite of some constraints, majority of participants indicated that they regularly attendant the IPM-FFS and they had engaged in programme activities on their self interest for improving their agro-ecological sound farming skills with special reference to cotton, which shows EFW/F created inter-personal trust among FFS participants on IPM-FFS training programme that is essential for working mutually and evolving innovations. It was suggested that the farmers can be good source for transferring the obtained knowledge of agro-ecological sound IPM practices to their community. Regarding this, agriculture extension needs to play an important role to support and persuade farmers who were participated and trained in IPM-FFS series of trainings during the years 2001 to 2004 .

\section{References}

Bartlett, A. (2005). Farmer field schools to promote integrated pest management in Asia: the FAO experience case study presented to the "Workshop on scaling up case studies in agriculture". International Rice Research Institute. pp. 16-18

Braun, A. and Duveskog, D. (2010). The farmer field school approach: History, global assessment \& success stories. Background paper for the IFAD rural poverty report. p. 20

Chukwuone, N. A., Agwu, A. E. and Agwu. N. (2006). Constraints and strategies toward effective cost-sharing of agricultural technology delivery in Nigeria: perception of farmers and agricultural extension personnel. Journal of Agricultural and Extension Education, AIAEE. V. 13 (1).

FAO, (2002). International code of conduct on the distribution and use of pesticides. Internet WWW page, at URL: http://www.fao.org/docrep/005/ y4544e/y4544e00.htm (accessed 21/02/2009).

FAO, (2004). Fertilizer use by crop in Pakistan. Land and plant nutrition management service land and water development division. Food and Agriculture Organization of the United Nations, Rome, Italy.

Feder, G., Murgai, R. and Quizon, J. B. (2004). The acquisition and diffusion of knowledge. The case of pest management training in farmer field schools, Indonesia. Journal of Agricultural Economics 55(2): 217-239. 
Fitz-Gibbon, C. T. and Morris, L. L. (1987). How to analyze data. London: Sage Publications. The International Professional Publisher.

Godtland, E. M., Sadoulet, E., Janvry, A. D., Murgai, R. and Ortiz, O. (2004). The impact of Farmer field schools on knowledge and productivity: A study of potato farmers in the Peruvian Andes. Economic Development and Cultural Change, 53: 63-92.

GoP, (2011). Agricultural Statistics of Pakistan, Ministry of Food, Agriculture and Livestock (Economic Wing), Islamabad.

Kenmore, P. (2002). Integrated Pest Management. International Journal of Occupational and Environmental Health 8(3): 173-174.

Khan, M. A. and Muhammad, I. (2005). Sustainable cotton production through skill development among farmers: Evidence from Khairpur District of Sindh, Pakistan - Article provided by Pakistan Institute of Development Economics in its journal The Pakistan Development Review. 44: 695-716

Khan, M. A., Ahmed, I. and walter-Echolas, G. (2005). Impact of FFS based IPM approach on farmer capacity, production practices and income: Evidence from Pakistan. The impact of the FAO EU IPM Programme for cotton in Asia. Pesticide Policy Project, Hannover. Special Issue Publication Series, No, 9. pp. 45-58

Kingsley, M. (1999). Season of learning: From field schools to farmers organized management: Extension and Advocacy. Farmer and NGO experiences in Indonesia. Jakarta. World Education.

Linh, N. (2001). Agricultural Innovation. Multiple grounds for technological policies in the red river delta of Vietnam. Wageningen University. Published Doctoral Dissertation. Internet WWW page, at URL: http:// library.wur.nl/WebQuery/wdab/1609995 (accessed 07/02 /2008).

Mallah, G. H., and Korejo, A. K. (2007). Establishment of integrated pest management (IPM) in cotton through farmer field school (FFS) in Sakrand, Sindh, Pakistan. Pak. J. Bot. 39 (7): 2693-2697.

McMillan, J. H. (2008). Educational Research: Fundamentals for the consumers, (5th Edition). Boston: Pearson-Allyn and Bacon.

Reddy, S. V. and Suryamani, M. (2005). Impact of farmer field school approach on acquisition of knowledge and skills by farmers about cotton pests and other crop management practices: Evidence from India. Pesticide Policy Project Publication Series No. 9, Hannover University, Germany. 
Rola, A., Jamias, S. and Quizon, J. (2002). Do farmer field school graduates retain and share what they learn? An investigation in Iloilo, Philippines. Journal of International Agricultural and Extension Education 9: 65-76.

Thiele, G., Nelson, R., Ortiz, O. and Sherwood, S. (2001). Participatory research and training: Ten lessons from the farmer field schools in the Andes. Internet WWW page, at URL: http:/www.prgaprogram.org/ External\%20Review\%20Web/Other\%20Publications/CIP/Thiele_2001. pdf (accessed 13/01/2007).

Tripp, R., Wijeratne M. and Piyadasa, V. H. (2005). What should we expect from farmer field schools? "A Sri Lanka case study". World Development, 33: $1705-1720$.

Wunsch, D. R. (1986). Survey Research: Determining sample size and representative response. In K. W. Brown (Ed.). Action Research in Business Education. pp. 31-34. 